\title{
An Exploratory Study of Middle Manager's Roles in Continuous Improvement
}

\author{
Freek J. A. Hermkens ${ }^{1}$, A. Georges L. Romme ${ }^{1} \&$ Sharon A. M. Dolmans ${ }^{1}$ \\ ${ }^{1}$ Eindhoven University of Technology, Eindhoven, Netherlands \\ Correspondence: Freek J. A. Hermkens, Eindhoven University of Technology, Department of Industrial \\ Engineering \& Innovation Sciences, P.O. Box 513, 5600 MB Eindhoven, The Netherlands.
}

Received: March 17, 2020

Accepted: April 3, $2020 \quad$ Online Published: April 8, 2020

doi:10.5539/ibr.v13n5p9

URL: https://doi.org/10.5539/ibr.v13n5p9

\begin{abstract}
Floyd and Wooldridge have developed a widely used model regarding the middle managers' contribution to strategic change, in which four strategic roles for middle managers are considered: championing, synthesizing, facilitating and implementing. Although there is an extensive body of knowledge about the roles and influence of middle managers in implementing strategy, insight in which roles are activated in continuous improvement (CI) initiatives is underdeveloped and highly dispersed. Therefore, in this study we seek to understand which middle management roles (i.e. championing, synthesizing, facilitating, implementing) contribute to accomplishing CI. To explore which of these roles are activated when middle managers are confronted with a CI initiative, we developed a scenario experiment. Our findings indicate that the implementing and synthesizing roles appear to be of key importance in the context of CI initiatives, while the facilitating and championing roles appear to be less relevant.
\end{abstract}

Keywords: continuous improvement, middle management, implementation, synthesis, experiment

\section{Introduction}

Accomplishing continuous improvement (CI) in an organization is a challenging process and demands substantial organizational changes as well as commitment of the people involved (Drew et al. 2004). While most of these changes are initiated as sustainable improvement plans, they often end up as a quick fix without deliberate efforts to create and maintain the conditions needed (Bhasin 2011, 2012a; Bhuiyan et al. 2006; Snee 2010). Accomplishing CI thus requires a sustainable change in mindset and behavior among the organization's top and middle management (Hermkens et al. 2017; Mann 2009).

Creating a CI culture requires creating new ways of working (i.e. continuously improving operational processes) and it requires that $\mathrm{CI}$ is integrated as a core activity in the daily routines of the organization (Anicich \& Hirsh 2017; Bateman 2005; Bateman \& David 2002; Fine et al. 2008; Holmemo \& Ingvaldsen 2016). Middle managers can be considered to be key agents in facilitating this kind of change and striking a functional balance between continuity and change (Embertson 2006; Guo et al. 2017; Huy 2002; Moss Kanter 1982). Their unique position between operational and top management and their knowledge about what motivates the employees in their unit or department (Huy 2001; Moss Kanter 1982) allows middle managers to enhance the chances of realizing sustainable change (Currie \& Procter 2005; Engle et al. 2017; Floyd \& Wooldridge 1992, 1997; Moss Kanter 1982). As accomplishing CI requires a controlled change strategy (Bhasin 2011, 2012a), middle managers can play an important role during this change as they can help to bridge the gap between top management and employees at the operational level (Ahearne et al. 2014; Gatenby et al. 2015; Kim et al. 2014; Likert 1961; Raes et al. 2011; Shi et al. 2009; Stoker \& De Korte 2001). Their unique position and pivotal role makes middle managers important for strategical renewals (Floyd \& Lane 2000; Osterman 2008; Raes et al. 2011; Wooldridge et al. 2008) such as CI (Collis 2016; Jayaram et al. 2008; Rahman et al. 2010). Middle managers translate top management strategy into operational activities and at the same time need to pay attention to problems on the shop floor on a daily basis (Anicich \& Hirsh 2017; Currie \& Procter 2005; Floyd \& Lane 2000; Sims 2003).

With regard to middle managers' contribution to strategic change, a widely-cited model is that of Floyd and Wooldridge $(1992,1996,1997)$, who link organizational performance directly to middle management. Floyd and Wooldridge (1992, 1996, 1997) define four strategic roles for middle managers: Championing, Synthesizing, 
Facilitating and Implementing. These four roles provide "a framework that combines upward and downward influence with behaviors that integrate and support strategies on one hand and diverge from official strategy on the other" (Floyd \& Wooldridge 1996, p. 42).

Middle managers perform a downward support role by implementing deliberate strategy through the translation of objectives from top management into effective operational plans, and an upward influence role by synthesizing information for top management, thus filtering important strategic feedback upwards (Tarakci et al. 2018; Van Rensburg et al. 2014). Middle managers can also facilitate in a downward manner, in the search for new strategic initiatives and adaptability by organizational experiments; and successful experiments can be championed upward to top management (Tarakci et al. 2018; Van Rensburg et al. 2014).

In sum, middle managers' integrative role is important for organizational performance while the divergent role is more important for organizations that want to innovate (Floyd \& Wooldridge, 1997). Although there is a broad body of knowledge about the roles and influence of middle management in implementing strategy, insight in which roles are activated in CI initiatives is underdeveloped and highly dispersed. Therefore, in this study we seek to understand which middle management roles (i.e. championing, synthesizing, facilitating, implementing) contribute to accomplishing CI?

To this end, we developed a scenario experiment to explore which of these roles are activated when middle managers are confronted with a CI initiative. Our findings indicate that some middle management roles appear to be of key importance in the context of CI initiatives, such as the implementing and synthesizing roles, while the facilitating and championing roles appear to be less relevant. The remainder of this article is structured as follows. First, we further explore CI initiatives and middle manager roles in the following section. We then describe our experimental method and procedure. After that, we report the results on which middle manager roles are likely to contribute to accomplishing CI. Finally, we discuss our findings and the implications for both theory and practice, followed by several conclusions.

\section{Theoretical Perspective}

This study aims to enhance our understanding of Floyd and Wooldridge's middle manager roles in the context of CI initiatives. In this section, we further develop the theoretical background of this study.

\subsection{Floyd and Wooldridge's Middle Management Roles}

Middle managers are crucial in connecting top management's vision to the shop floor (Ahearne et al. 2014; Heyden et al. 2017; Holmemo \& Ingvaldsen 2016; Kras et al. 2017). Their involvement in the formation of strategy is thus associated with the improvement of organizational performance (Mair 2017; Ouakouak et al. 2014; Wolf \& Floyd 2017). In this respect, there are two ways in which middle management involvement could enhance organizational performance: higher quality strategic decisions and more efficient implementation (Wooldridge \& Floyd 1990).

Floyd and Wooldridge $(1992,1996,1997)$ and Wooldridge et al. (2008) identified four 'roles' through which middle managers can influence organizational performance. These roles (Floyd \& Wooldridge 1992) are:

- Championing strategic alternatives: the middle manager engages in persistent and persuasive communication of proposals that either provide the firm with new capabilities or allow the firm to use existing capabilities differently.

- Facilitating adaptability: the middle manager encourages cross-functional problem solving, experimentation and idea generation, and creates arrangements that increase organizational flexibility.

- Synthesizing information: the middle manager derives strategic meaning from events, connects ideas to strategic issues, and sells issues to top management and others in the organization.

- Implementing deliberate strategy: the middle manager aligns the unit's actions with the firm's strategic intent.

These four roles (figure 1) provide "a framework that combines upward and downward influence with behaviors that integrate and support strategies on one hand and diverge from official strategy on the other" (Floyd \& Wooldridge 1996, p. 42). Downward influence impacts how well the organization is aligned with the new strategy, whilst upward influence affects the opinion of top management on organizational circumstances and alternative strategic options. Divergent ideas are not in line with the organization's given strategy, whereas integrative ideas support the organization's strategic alignment (Floyd \& Wooldridge 1996). Thus, depending on the organizational context, type of strategic change, issues faced by top management, and leadership style of top managers, as well as their personal disposition, middle managers can play one or more of these roles (Floyd \& 
Wooldridge 1992, 1994, 1997; Floyd \& Lane 2000).

\begin{tabular}{|l|l|l|l|}
\hline \multirow{2}{*}{} & \multicolumn{3}{|c|}{ Behavioral dimension } \\
\hline \multirow{4}{*}{$\begin{array}{l}\text { Cognitive } \\
\text { dimension }\end{array}$} & Divergent & Championing & Downward \\
\cline { 2 - 4 } & Integrative & $\begin{array}{l}\text { Synthesizing } \\
\text { information }\end{array}$ & $\begin{array}{l}\text { Implementing } \\
\text { deliberate strategy }\end{array}$ \\
\hline
\end{tabular}

Figure 1. Middle management's four strategic roles (Floyd \& Wooldridge 1992, 1996; Jaoua 2016; Neto \& Lavarda 2017)

Middle managers should be engaged with strategy implementation due to their structural positions in managing resources, providing information to decision makers and communicating strategic intent of top management throughout the organization (Salih \& Doll 2013). Their integrative strategic behaviors entail implementing the deliberate organizational strategy by translating it to lower levels and synthesizing new information to top management regarding implementation (Floyd \& Wooldridge 1992; Van Rensburg et al. 2014). Table 1 provides illustrations of the behaviors typical to each role.

Table 1. Examples of middle management's strategic influence activities in each strategic role (Floyd \& Wooldridge 1997, p. 467)

\begin{tabular}{|l|l|}
\hline Upward & \\
\hline Synthesizing information & $\begin{array}{l}\text { Gather information on the feasibility of new programs } \\
\text { Communicate the activities of competitors, suppliers, etc. } \\
\text { Assess changes in the external environment }\end{array}$ \\
\hline Championing & $\begin{array}{l}\text { Justify and define new programs } \\
\text { Evaluate the merits of new proposals } \\
\text { Search for new opportunities } \\
\text { Propose programs or projects to higher level managers }\end{array}$ \\
\hline Downward & $\begin{array}{l}\text { Relax regulations to get new projects started } \\
\text { 'Buy time' for experimental programs } \\
\text { Locate and provide resources for trial projects } \\
\text { Provide a safe haven for experimental programs } \\
\text { Encourage informal discussion and information sharing }\end{array}$ \\
\hline Implementing deliberate strategy & $\begin{array}{l}\text { Monitor activities to support top management objectives } \\
\text { Translate goals into action plans } \\
\text { Translate goals into individual objectives } \\
\text { Sell top management initiatives to subordinates }\end{array}$ \\
\hline
\end{tabular}

To conclude, middle managers typically play a significant role during change (Balogun 2003; Balogun \& Johnson 2004, Floyd \& Wooldridge 1992, 1997), and make a major contribution towards achieving of top management's strategic ambitions (Balogun 2003; Currie \& Procter 2005; Van Rensburg et al. 2014) by implementing top-level decisions and coordinating activities at the operational level (Floyd \& Lane 2000).

\subsection{Continuous Improvement}

Continuous Improvement (CI) is one of the most frequently sought-after organizational change initiatives. CI can be defined as a culture of sustained improvement in which all members of the organization contribute to 
performance improvement by continuously realizing small changes in their work processes (Jørgensen et al. 2003). Not surprisingly, many organizations strive for CI in hope of improving performance, staying competitive and lowering costs (Bhuiyan et al. 2006; Nyhuis et al. 2010; Snee 2010). Many organizations in financial services and other industries effect a strategy of CI to adapt to their changing environment (Bessant et al. 2001; Bhuiyan et al. 2006; Collis 2016).

Hernández and Mateo (2012) describe continuous improvement as an ongoing effort to continuously improve products, services or processes, which can be incremental over time or take the form of larger breakthrough improvements. Due to its popularity, CI practices such as Lean have developed and become more professional in recent years (Aloini et al. 2011; Hines et al. 2011; O’Rourke 2005; Rother 2010). While the initial focus was on cutting cost, CI methods have evolved towards an emphasis on changing the organizational culture (Basu \& Ahmed 2012; O'Rourke 2005). In this respect, Dale (1996) describes CI as the means to enhance process performance on a continual basis. The primary focus of CI practices such as Lean is to eliminate activities that do not add customer value and simultaneously address value-adding activities (Cudney \& Elrod 2011).

Yet, achieving CI often proves to be difficult (Bateman 2005). CI initiatives have to be included in the organizational culture; otherwise they will fail (Bicheno 2008). As such, CI implementations such as Lean are less likely to be successful if one or more of the following conditions exist in the organization: the absence of a CI culture, short-term commitment (if any) among middle managers and employees, lack of knowledge transfer regarding CI, or too much focus on tools and techniques. In these conditions, the execution of CI practices is not likely to lead to any significant improvements in organizational behavior and performance (Atkinson 2010; Bhasin 2011, 2012a, 2012b; Cudney \& Elrod 2011; Dahlgaard \& Dahlgaard-Park 2006; Holweg 2007; Saurin et al. 2011). As such, the momentum of CI efforts often comes to a halt, after which the organization falls back into its established routines (Bateman \& David 2002; Hines et al. 2018).

As a result, it appears that organizational culture is important to achieve a CI practice over time. Top management has to reinforce a culture of CI and make it successful through management and workers' involvement and active participation (Angelis et al. 2011; Boyle et al. 2011; McLean et al. 2017). If employees do not feel sufficiently involved, this can have a negative effect on the execution of CI (McLean et al. 2017; Van Assen 2016).

Research shows that middle managers play an important role in enabling and sustaining change in organizations (Huy 2002). They can enable organizational change, because they may have value-adding ideas for making the organization better and tend to have a big informal network as well as detailed knowledge about what motivates each employee (Huy 2001, 2002; Moss Kanter 1982). Moss Kanter (1982) therefore argues that the success of any attempt to improve performance is directly related to the creative and innovative skills of the middle manager. By focusing on the role of the middle manager, an organization can make the implementation process successful (Found et al. 2009) and gain more sustainable results in terms of savings, customer satisfaction and reaching CI within the organization. Previous studies acknowledge the role of the middle managers in facilitating change into a lean organization and making it adhere. However, as Osterman (2008, p.2) states: "our understanding of middle management is remarkably thin, compared with research conducted on higher management". Hence, more insight is needed to understand which middle management roles are likely to contribute to accomplishing CI.

\section{Method and Procedure}

To investigate which middle manager roles may contribute (in particular) to achieving CI, we draw on an exploratory quasi-natural experimental design (Miles et al. 2014; Saunders et al. 2009), involving 107 middle managers working within a large bank. As part of the experiment, the managers were first asked to complete an existing self-test questionnaire (Floyd \& Wooldridge 1996) to characterize their natural individual middle manager role profile. Subsequently, managers were asked to evaluate a realistic, yet fictitious scenario of a CI initiative by indicating how they perceived this initiative and what action they would take. This experimental setup allows us to explore which middle managers roles are most likely to contribute to achieving CI.

\subsection{Data Collection}

This experiment was carried out at a large bank in the Netherlands. Based on the lead author's extensive professional experience within banks, a hypothetical scenario of a bank, called "The Piggy Bank", was prepared. As part of the experiment, all participants received the scenario in which they work as a manager at "The Piggy Bank". The scenario describes top management's request to the mangers (participants) to implement the CI initiative "GOLD". 


\subsection{Sample Selection}

To obtain participants for the experiment, one of the authors contacted program managers (involved in CI changes) and management team members from the various business lines within the bank to construct a list of the names and business e-mail addresses of all middle managers. This resulted in a total number of 474 potential participants. Each of these middle managers received an e-mail including a password-protected link to the online environment. The unique login information ensured confidentiality of their responses. The participants were asked to provide the following personal information: gender, age, business line, reporting line, level of education, years of experience at the bank, years of experience at current department, and years of experience with CI.

\subsection{Questionnaire Development}

To collect the experimental data, the authors made use of two lists of statements. The "Self-test of Middle Management Strategic Involvement Integrative Behavior" (Floyd \& Wooldridge 1996) was used to capture middle manager roles. This is a validated list of statements (see appendix 1) to determine the different roles of the middle manager. The middle manager can indicate on the basis of a 5-point Likert scale (never, rarely, sometimes, regularly or often) to what extent he or she has a preference for the activities mentioned.

Second, based on the professional experience of one of the authors in working with various middle managers at a bank, we developed a questionnaire to capture the middle managers' perception of the CI initiative as well as their intended response or action (see appendix 2) with respect to e.g. culture, customer satisfaction, efficiency, role, job security, work atmosphere and top management support (De Waal 2018; Delizonna 2017; Netland 2016; Nguyen 2018; Sreedharan \& Sunder 2018). To ensure that the experiment and the questionnaire reflect a realistic situation, the research team pre-tested the experiment. This test included eight employees of the bank participating in this study and four employees of other large banks where a similar CI program was introduced. Based on their feedback, the experiment was further refined.

\subsection{Characteristics of the Sample}

Table 2 provides descriptive information on the sample of middle managers participating in this study. The sample of participants included 72 male $(67,3 \%)$ and 35 female $(32,7 \%)$ managers, ranging in age from 33 to $64(\mathrm{M}=$ 47.3). On average, the participants had 3,4 years of experience in working with CI. In terms of work experience, 95 $(88,8 \%)$ participants had more than ten years of experience. In terms of the highest level of education obtained, 6 managers hold a postgraduate degree $(5,6 \%), 37$ hold a master's degree $(34,6 \%)$ and 58 have a bachelor's degree $(54,2 \%)$.

Table 2. Descriptive statistics of the sample

\begin{tabular}{|c|c|}
\hline & Mean/Frequency \\
\hline $\mathbf{N}$ & 107 \\
\hline Male & $72(67.3 \%)$ \\
\hline Female & $35(32.7 \%)$ \\
\hline Mean age (in years) & 47.27 \\
\hline \multicolumn{2}{|l|}{ Experience (in years) } \\
\hline $0-2$ & $3(2.8 \%)$ \\
\hline $3-5$ & $2(1.8 \%)$ \\
\hline $6-10$ & $7(6.5 \%)$ \\
\hline$>10$ & $95(88.8 \%)$ \\
\hline \multicolumn{2}{|l|}{ Experience department (in years) } \\
\hline $0-2$ & $47(43.9 \%)$ \\
\hline $3-5$ & $31(28.9 \%)$ \\
\hline $6-10$ & $20(18.7)$ \\
\hline$>10$ & $9(8.4 \%)$ \\
\hline Mean experience with CI (in years) & 3.4 \\
\hline
\end{tabular}




\begin{tabular}{|r|l|}
\hline Highest degree \\
\hline Postgraduate & $6(5.6 \%)$ \\
\hline University & $37(34.6 \%)$ \\
\hline HBO & $58(54.2 \%)$ \\
\hline MBO & $2(1.9 \%)$ \\
\hline High school & $4(3.7 \%)$ \\
\hline
\end{tabular}

\subsection{Experiment}

The participating middle managers received a scenario in which they are a manager at 'The Piggy Bank'. The scenario describes how The Piggy Bank is going through turbulent times. This bank's top management wants to improve the cost-income ratio every year, but is facing stricter requirements of regulators; moreover, they want any changes not to come at the expense of customer satisfaction. At the same time, the (banking) world is not free from radical changes. In order to be able to cope with all these changes, top management aims to roll out the "GOLD" CI program in this bank, with the help of the manager (participant).

Before reading and evaluating the scenario, the participants were asked to fill out the self-test developed by Floyd and Wooldridge (1996) (see Appendix 1). The purpose of this self-test is to get a general picture of the middle manager role. After the participants had read the scenario, they were asked to answer the newly developed questionnaire on the basis of the scenario description (see Appendix 2).

\subsection{Questionnaire}

The questionnaire includes 22 statements (see table 3 ) that aim to capture both how middle managers perceive CI initiatives and what actions they would take to put this into practice. We focus particularly on these dimensions because they are vital and critical aspects of the practice of CI programs (e.g. De Waal 2018; Delizonna 2017; Netland 2016; Nguyen 2018; Sreedharan \& Sunder 2018). First drafts of these statements were discussed with several managers in the financial service industry to make sure the statements were realistic and representative of how middle managers evaluate such initiatives, and adapted accordingly. This resulted in statements more focused on the perception of the middle managers (e.g. "I consider Gold as an implementation of the CI philosophy") and statements more focused on the actual practice (e.g. "I will steer the department on achieving CI"). This distinction is made because in practice there is often a discrepancy between the actual practice and perception of middle managers (e.g. Argyris 2004; Van Baarle et al. 2019). In this respect, there is a difference between what middle managers say they are going to do and what they will actually do (e.g. Argyris 2004). The statements reflect important dimensions of CI initiatives such as culture, customer satisfaction, efficiency, own role, job security, work atmosphere, tool and top management support. In addition, they correspond to the experiences from the professional practice of one of the researchers. Participants were asked to respond to the statements on a 5-point Likert scale (totally disagree - disagree - agree nor disagree - agree or totally agree).

Table 3. Statements used in experiment grouped on basis of CI aspects

\begin{tabular}{|c|c|l|}
\hline Perception & CI aspects & \multicolumn{1}{c|}{ Statements } \\
\hline 1 & Culture & I consider GOLD as an implementation of the continuous improvement philosophy. \\
\hline 2 & Culture & $\begin{array}{l}\text { I consider GOLD as a program that results in a permanent shift of our organizational } \\
\text { culture. }\end{array}$ \\
\hline 5 & Culture & GOLD results in the implementation of continuous improvement within our culture. \\
\hline 3 & Efficiency & I consider GOLD as an effort to increase the efficiency of the organization. \\
\hline 6 & Efficiency & GOLD results in a drastic cost decrease. \\
\hline 7 & Work atmosphere & The working atmosphere will improve due to the implementation of GOLD \\
\hline 4 & Job security & I consider GOLD as a threat to my function. \\
\hline Practice & Own role & I perceive my role as crucial within the GOLD program. \\
\hline 13 & Culture & $\begin{array}{l}\text { I will integrate GOLD and adapt it to the current way of working within my } \\
\text { department(s) }\end{array}$ \\
\hline 22 & Culture & $\begin{array}{l}\text { Because of GOLD, I will steer the department on achieving continuous improvement } \\
\text { and the adaption to a new organizational culture. }\end{array}$ \\
\hline 20 & Efficiency & Because of GOLD, I will steer the department on efficiency. \\
\hline 17 & Efficiency & I will determine specific KPI's to timely realize the efficiency objectives of GOLD. \\
\hline 18 & Efficiency & In the context of GOLD, I actively monitor individual and team KPI's in order to \\
\hline
\end{tabular}




\begin{tabular}{|c|l|l|}
\hline 19 & Own role & identify improvement possibilities. \\
\hline 9 & Own role & I will fulfil a pioneering role in making GOLD a success. \\
\hline 11 & $\begin{array}{c}\text { Customer } \\
\text { satisfaction }\end{array}$ & Because of GOLD, I focus on fulfilling customer needs. \\
\hline $\begin{array}{c}\text { Customer } \\
\text { satisfaction }\end{array}$ & $\begin{array}{l}\text { In the context of GOLD, I will adapt the organization in order to meet customer needs in } \\
\text { the best possible way. }\end{array}$ \\
\hline 14 & $\begin{array}{c}\text { Customer } \\
\text { satisfaction }\end{array}$ & $\begin{array}{l}\text { Because of GOLD, I focus on fulfilling customer needs at the lowest possible costs and } \\
\text { shortest lead time. }\end{array}$ \\
\hline 21 & $\begin{array}{c}\text { Customer } \\
\text { satisfaction }\end{array}$ & Because of GOLD, I will steer the department on customer satisfaction. \\
\hline 12 & Tool & I select the proper tools to achieve and monitor the GOLD objectives. \\
\hline 8 & $\begin{array}{c}\text { Top management } \\
\text { support }\end{array}$ & I will support top management during the implementation of the change (GOLD). \\
\hline
\end{tabular}

\section{Results}

Table 4 reports the results of the experiment (see also Appendix 2). We found significant P-values regarding the four Floyd and Wooldridge roles on 17 out of the 22 statements. These are statements concerning dimensions of CI such as culture, customer satisfaction, efficiency, own role, job security, work atmosphere, tool and top management support. The results show that the implementing and synthesizing roles in particular play a role in activating middle managers to achieve CI.

Table 5 provides an additional overview of the results, with the statements grouped on the basis of role significance. This table shows that the implementing role, in particular, plays a role in activating middle managers to achieve CI. More specifically, the implementing role has a significant P-value, a high F-value and a positive B-value in 11 statements. This suggests that the implementing role has a positive impact on the different statements regarding $\mathrm{CI}$.

The synthesizing role has a significant P-value and a high F-value in 8 statements. However, Table 5 also implies that four statements regarding the synthesizing role have a positive B-value and four statements have a negative B-value. With regard to the synthesizing role, two negative B-values (regarding statements 4 and 20) can be interpreted as a positive impact. So, based on these results the synthesizing role appears to have a positive influence on achieving CI.

Moreover, our results show that the facilitating role (i.e. 3 statements) and championing role ( 1 statement) are less likely to be activated in CI initiatives. For the facilitating role, we found a significant $\mathrm{P}$-value and a high F-value in 3 statements. Regarding these 3 statements, Table 5 implies that we have 1 statement with a positive B-value and 2 statements have a negative B-value. But the negative B-values (regarding statement 4 and 19) can be interpreted as a positive impact. So, based on these results the facilitating role appears to make a minor contribution to achieving CI.

The championing role has a significant P-value and a high F-value for one statement (statement 19), with a positive B-value that can be interpreted as implying a negative impact. 
Table 4. Results of regression analyses

\begin{tabular}{|c|c|c|c|c|c|c|c|c|c|c|c|c|c|c|c|c|c|c|c|c|c|c|}
\hline \multirow[t]{2}{*}{ Statement } & \multicolumn{2}{|l|}{1} & 3 & 4 & 5 & 6 & 7 & 8 & 9 & 10 & 11 & 12 & 13 & 14 & 15 & 16 & 17 & 18 & 19 & 20 & 21 & 22 \\
\hline & $B$ & $B$ & $B$ & $B$ & $B$ & $B$ & $B$ & B & $B$ & $B$ & $B$ & $B$ & B & $B$ & $B$ & $B$ & $B$ & $B$ & $B$ & B & $B$ & $B$ \\
\hline Championing & .046 & .036 & -019 & .062 & -.029 & -.070 & -.022 & -.016 & -.020 & -.030 & -.003 & .054 & -038 & 0.19 & .057 & .015 & 0.23 & .037 & $.074^{* *}$ & .071 & .007 & -017 \\
\hline Facilitating & .015 & -021 & -013 & $-.065^{* *}$ & .036 & -007 & -013 & -041 & .021 & $.058^{* *}$ & .006 & -016 & .027 & .005 & -002 & -009 & -012 & -.062 & $-063^{* *}$ & .007 & .016 & .031 \\
\hline Synthesizing & -034 & .024 & .031 & $-065^{* *}$ & .046 & $.067^{*}$ & $.068^{* *}$ & $.070^{* *}$ & $.082^{* * *}$ & .041 & .029 & .034 & $-.072^{*}$ & .008 & .001 & .008 & .008 & -.027 & -.024 & $-.098^{* *}$ & .003 & $-.074^{*}$ \\
\hline Implementing & $.062^{*}$ & $.071^{*}$ & $.096^{* * *}$ & .012 & $.071^{*}$ & .053 & $.057^{*}$ & $.058^{* *}$ & .034 & .006 & .030 & .024 & $.161^{* * *}$ & .018 & .010 & $.074^{* * *}$ & $.124^{* * * *}$ & $.143^{* * *}$ & -021 & -.036 & .033 & $.086^{* *}$ \\
\hline Gender & .173 & .270 & -001 & -397 & .308 & -120 & .156 & .138 & .076 & .259 & .076 & .373 & .432 & .051 & .103 & -.050 & .112 & -.059 & -229 & 148 & -221 & -159 \\
\hline Age & .025 & .007 & .003 & .025 & -011 & -010 & .009 & .003 & .000 & .007 & .005 & .006 & .003 & .013 & .022 & -.003 & -.020 & .000 & -.007 & .006 & .029 & .002 \\
\hline Type of department & .033 & .164 & .123 & -139 & .077 & .023 & .100 & .117 & .092 & .033 & .068 & .055 & .140 & .055 & .025 & .057 & -095 & -.106 & .039 & -148 & .061 & .012 \\
\hline Education & .162 & -192 & -064 & -.033 & .049 & -196 & -076 & -096 & -142 & -.049 & .039 & -168 & .000 & -.013 & -.064 & -.055 & .179 & .077 & .020 & .078 & .095 & .246 \\
\hline \begin{tabular}{|l} 
Years at organization \\
\end{tabular} & -413 & -149 & -.048 & -.086 & -.003 & -.062 & -193 & -164 & .230 & -.131 & -233 & -.021 & .003 & -180 & -276 & -214 & -.008 & .058 & .039 & .004 & .040 & -.069 \\
\hline Years at department & .102 & .125 & .054 & .117 & -.029 & -120 & .057 & -.077 & .055 & -.015 & -.049 & .087 & .154 & .054 & .048 & .084 & .113 & .057 & -.011 & -.028 & -110 & -.008 \\
\hline Years of improvement experience & -027 & -.060 & -038 & -.077 & -.061 & -.007 & -012 & .037 & .029 & .006 & .048 & -.012 & -093 & .012 & -.038 & .007 & -.017 & .010 & -143 & .020 & .044 & .008 \\
\hline Philosophy & .144 & .426 & -.049 & -284 & .561 & -.067 & .504 & .144 & .159 & -135 & .561 & -179 & .085 & .072 & -121 & .051 & .234 & .063 & .173 & -015 & 350 & .492 \\
\hline Pressure & .245 & .021 & .293 & -186 & .222 & -013 & .341 & .210 & .063 & .035 & .042 & -.007 & .093 & .245 & .151 & .152 & -156 & -.362 & -272 & .029 & .121 & .039 \\
\hline Constant & 1.469 & 1.663 & 2.151 & 3.389 & .713 & 3.998 & 3.067 & 4.102 & 3.810 & 3.408 & 2.466 & 2.508 & 1.863 & 2.647 & 2.510 & 3.342 & 1.009 & 1.418 & 4.374 & 3.037 & 1.263 & 1.760 \\
\hline \begin{tabular}{|l|}
$\mathrm{N}$ \\
\end{tabular} & 107 & 107 & 107 & 107 & 107 & 107 & 107 & 107 & 107 & 107 & 107 & 107 & 107 & 107 & 107 & 107 & 107 & 107 & 107 & 107 & 107 & 107 \\
\hline
\end{tabular}

We also found that 4 statements have a significant score on both integrative roles. However, 2 out of the 4 statements had a combined positive and negative effect (B- value) from the 2 roles involved (in table 5: statements 13 and 22), making it difficult to draw a clear conclusion. Also, one statement has significant results on both divergent roles, but again a combined positive and negative effect was found on the 2 roles involved (statement 19); thus, here we can also not draw a clear conclusion.

Remarkably, none of the four roles show any significant evidence for the five statements regarding customer satisfaction.

Table 5. Statements used in experiment, grouped on the basis of role significance

\begin{tabular}{|c|c|l|c|c|}
\hline Perception & CI aspects & Statements & $\begin{array}{l}\text { Significant } \\
\text { Role }\end{array}$ & Effect \\
\hline 1 & Culture & $\begin{array}{l}\text { I consider GOLD as an implementation of the } \\
\text { continuous improvement philosophy. }\end{array}$ & Implementing & Positive \\
\hline 2 & Culture & $\begin{array}{l}\text { I consider GOLD as a program that results in a } \\
\text { permanent shift of our organizational culture. }\end{array}$ & Implementing & Positive \\
\hline 5 & Culture & $\begin{array}{l}\text { GOLD results in the implementation of } \\
\text { continuous improvement within our culture. }\end{array}$ & Implementing & Positive \\
\hline 3 & Efficiency & $\begin{array}{l}\text { I consider GOLD as an effort to increase the } \\
\text { efficiency of the organization. }\end{array}$ & Implementing & Positive \\
\hline 6 & Efficiency & GOLD results in a drastic cost decrease. & Synthesizing & Positive \\
\hline 7 & Work atmosphere & $\begin{array}{l}\text { The working atmosphere will improve due to the } \\
\text { implementation of GOLD }\end{array}$ & $\begin{array}{l}\text { Implementing/ } \\
\text { Synthesizing }\end{array}$ & $\begin{array}{l}\text { Positive/ } \\
\text { Positive }\end{array}$ \\
\hline 4 & Job security & $\begin{array}{l}\text { I consider GOLD as a threat to my function. } \\
\text { Negative/ } \\
\text { Negative }\end{array}$ \\
\hline 10 & Own role & $\begin{array}{l}\text { I perceive my role as crucial within the GOLD } \\
\text { program. }\end{array}$ & Facilitating & Positive \\
\hline Practice & Efficiency & $\begin{array}{l}\text { I will determine specific KPI's to timely realize } \\
\text { the efficiency objectives of GOLD. }\end{array}$ & Implementing & Positive \\
\hline 17 & Efficiency & $\begin{array}{l}\text { In the context of GOLD, I actively monitor } \\
\text { individual and team KPIs in order to identify } \\
\text { improvement possibilities. }\end{array}$ & Implementing & Positive \\
\hline 18 & Tool & $\begin{array}{l}\text { I select the proper tools to achieve and monitor the } \\
\text { GOLD objectives. }\end{array}$ & Implementing & Positive \\
\hline 16 & Own role & $\begin{array}{l}\text { I will fulfil a pioneering role in making GOLD a } \\
\text { success. }\end{array}$ & Synthesizing & Positive \\
\hline 9 & Efficiency & $\begin{array}{l}\text { Because of GOLD, I will steer the department on } \\
\text { efficiency. }\end{array}$ & Synthesizing & Negative \\
\hline 20 & Culture & $\begin{array}{l}\text { I will integrate GOLD and adapt it to the current } \\
\text { way of working within my department(s) }\end{array}$ & $\begin{array}{l}\text { Implementing/ } \\
\text { Synthesizing }\end{array}$ & $\begin{array}{l}\text { Positive/ } \\
\text { Negative }\end{array}$ \\
\hline 13 & Because of GOLD, I will steer the department on & Implementing/ & Positive/ \\
\hline 22 & Culture & &
\end{tabular}




\begin{tabular}{|c|c|c|c|c|}
\hline & & $\begin{array}{l}\text { achieving continuous improvement and the } \\
\text { adaption to a new organizational culture. }\end{array}$ & Synthesizing & Negative \\
\hline 8 & $\begin{array}{l}\text { Top management } \\
\text { support }\end{array}$ & $\begin{array}{l}\text { I will support top management during the } \\
\text { implementation of the change (GOLD). }\end{array}$ & $\begin{array}{l}\text { Implementing/ } \\
\text { Synthesizing }\end{array}$ & $\begin{array}{l}\text { Positive/ } \\
\text { Positive }\end{array}$ \\
\hline 19 & Own role & $\begin{array}{l}\text { By implementing GOLD, I will solely focus on } \\
\text { activities that are beneficial for me. }\end{array}$ & $\begin{array}{l}\text { Facilitating/ } \\
\text { Championing }\end{array}$ & $\begin{array}{l}\text { Negative/ } \\
\text { Positive }\end{array}$ \\
\hline 11 & $\begin{array}{l}\text { Customer } \\
\text { satisfaction }\end{array}$ & $\begin{array}{l}\text { Because of GOLD, I focus on fulfilling customer } \\
\text { needs. }\end{array}$ & None & None \\
\hline 14 & $\begin{array}{l}\text { Customer } \\
\text { satisfaction }\end{array}$ & $\begin{array}{l}\text { In the context of GOLD, I will adapt the } \\
\text { organization in order to meet customer needs in } \\
\text { the best possible way. }\end{array}$ & None & None \\
\hline 15 & $\begin{array}{l}\text { Customer } \\
\text { satisfaction }\end{array}$ & $\begin{array}{l}\text { Because of GOLD, I focus on fulfilling customer } \\
\text { needs at the lowest possible costs and shortest lead } \\
\text { time. }\end{array}$ & None & None \\
\hline 21 & $\begin{array}{l}\text { Customer } \\
\text { satisfaction }\end{array}$ & $\begin{array}{l}\text { Because of GOLD, I will steer the department on } \\
\text { customer satisfaction. }\end{array}$ & None & None \\
\hline 12 & $\begin{array}{c}\text { Customer } \\
\text { satisfaction }\end{array}$ & $\begin{array}{l}\text { I will investigate how GOLD can contribute to } \\
\text { customer satisfaction. }\end{array}$ & None & None \\
\hline
\end{tabular}

\section{Discussion and Conclusions}

The role and added value of middle managers have been subject to debate for a long time (Dopson \& Stewart 1990, 1993; Harding et al. 2014; Tabrizi 2014). Some consider middle management to be a bureaucratic barrier (Guth \& MacMillan 1986; Hammer \& Champy 1993) or obstacle to change (Blom 2018; Cândido \& Santos 2019), even suggesting that middle management might cease to exist altogether (Clarke 1998, p. 191): "Middle management is an endangered species that has been delayered and subject to many change programs." Others, however, argue in strong favor of the role and impact of middle management, by regarding it as a strategic asset (Balogun 2003; Van der Voet et al. 2016) that can have an important contribution (Kuyvenhoven \& Buss 2011; Osterman 2008; Wooldridge et al. 2008), in particular in the context of responding to organizational change (Nonaka 1994). Despite the fact that scholars have argued that middle managers play an important role in facilitating change in organizations (Buick et al. 2018; Engle et al. 2017; Huy 2011), our understanding of middle management remains remarkably thin (Osterman 2008). Organizations in financial services and other industries are constantly trying to adapt to this ever-changing environment (Birkinshaw et al. 2008; Madhani 2017; Saha et al. 2017), among others by implementing a CI strategy (Bessant et al. 2001; Bhuiyan et al. 2006; Collis 2016). Therefore, in this study, we set out to explore which middle management roles (as established in the framework by Floyd and Wooldridge) may contribute to or hinder accomplishing organizational change in the form of CI.

Our findings indicate that some middle management roles appear to be of importance in the context of implementing CI initiatives, such as the implementing and synthesizing roles, while the facilitating and championing roles appear seems to be less relevant. In line with Floyd and Wooldridge (1997), our results suggest support for the integrative roles (i.e. implementing and synthesizing) that middle managers may engage in when top management seeks to adopt CI. However, for the synthesizing role we found a negative effect of this role on achieving CI (see statement 13 and 22). But, for the majority of the statements, there is a positive effect of the integrative roles. So, for our sample, one can state that middle managers who prefer an integrative role within the organization are more likely to perceive $\mathrm{CI}$ initiatives as a sustainable cultural change and are more likely to take action in this respect. According to Bessant and Francis (1999), the implementing role can be seen as a critical component in CI development, thereby helping to ensure that CI activities are in line with the organizational strategy developed by top management (Oakland 2011). Thus, for the integrative roles of implementing and synthesizing, our findings suggest that middle managers tend to help bridge the gap between top management and employees at the operational level, thereby translating top management strategy into operational activities (Ahearne et al. 2014; Anicich \& Hirsh 2017; Gatenby et al. 2015; Kim et al. 2014; Shi et al. 2009; Stoker \& De Korte 2001).

This study found less support for the two divergent roles of facilitating and championing as contributing to accomplishing CI. In the facilitating role, middle managers facilitate employees to exchange knowledge and information, to come up with new ideas, to experiment and realize CI (Floyd \& Lane 2000). One explanation for the lack of support for this role can be found in earlier research conducted by Delbridge and Barton (2002). They indicate that organizations tend to use external knowledge and skills for facilitating CI instead of placing this role with the current middle management. In addition, almost no support was found for the championing role 
with respect to accomplishing CI. In this role, middle managers may influence the change process by bringing innovative concepts to the attention of top management (Floyd \& Wooldridge 1996). This would for example imply that middle managers would develop alternatives to the current strategy and present them to top management (Floyd \& Wooldridge 1992). The insignificance of the championing role in the data analysis can possibly be explained by the fact that top management does often not support or appreciate divergent behavior (Floyd \& Lane 2000).

\subsection{Interpretation of Key Findings}

Understanding the role of middle managers is critical because, as stated by Tabrizi (2014): the key to change is middle management. In addition, Holmemo and Ingvaldsen (2016) define the middle manager as the missing link in Lean implementation. Our experiment aims to explain which middle management roles contribute to accomplishing CI. To achieve that, we have made the concept of CI practical by focusing on a number of important $\mathrm{CI}$ aspects such as culture, customer satisfaction, efficiency, own role, job security, work atmosphere and top management support (De Waal 2018; Delizonna 2017; Netland 2016; Nguyen 2018; Sreedharan \& Sunder 2018).

Regarding the embedding of $\mathrm{CI}$ in the culture of the organization, our study indicates that the implementing role of middle managers is probably a key driver for them to develop a deliberate intention toward embedding CI in the organization. For all statements related to the cultural aspect, there is a significant and positive correlation between the statement and the implementing role. Thus, our results underline the idea that middle managers are executors of the deliberate strategy created by top management (Floyd \& Wooldridge 1992; Nonaka 1994). This is important because creating a CI culture that needs to be sustained over many years requires the commitment, involvement and leadership of the entire management of the organization (Dahlgaard \& Dahlgaard-Park 2006; Snee 2010).

Furthermore, our results also show that the implementation role has a high degree of significance when it comes to efficiency statements. Out of the five statements related to efficiency aspect three have a significant relationship concerning the implementing role. The other two statements show significance related to the synthesizing role. This can be supported by the view that the pursuit of efficiency is an important point because optimized processes can increase reliability and increase competitiveness (Carlborg et al. 2013; Van Dun \& Wilderom 2016). By gathering information (synthesizing role) about competitors' activities and evaluating major changes in the business environment, middle managers can play an important role in accomplishing the necessary changes to stay competitive and contribute to accomplishing $\mathrm{CI}$ within the organization.

From a more integrative perspective, the implementing and synthesizing roles indicate a significant positive relationship between the (expected) work atmosphere and top management support. Our results suggest that middle managers pay attention to these $\mathrm{CI}$ aspects from the perspective of both roles. A possible explanation is that middle managers expect that executing CI may offer opportunities for learning and for new and extensive role interpretation (Angelis et al. 2011; McQuade 2008; Nelson \& Yeo 2012). Moreover, middle managers can increase the skills and knowledge of the entire workforce and stimulate workers to develop themselves (Lam et al. 2015; Poksinska et al. 2013; Van Assen 2018). In other words, middle managers can adopt a learning mindset and stimulate employee participation within the organization (Buick et al. 2018; Delizonna 2017; Vänje and Brännmark 2017). This underlines the idea that middle management enables the exchange of knowledge and new ideas and plays a key role in strategic renewal (Chandler 1977). Overall this is in line with the fact that an integrative role in support of intentional strategy is predefined and openly expected (Floyd \& Lane 2000).

As already mentioned, only a few of the statements indicated that there is a significant relationship with the facilitating and championing role. A possible explanation is the fact that divergent behavior is often not supported and appreciated by top management (Floyd \& Lane 2000).

Lastly, our findings imply no significant relationship between the statements about customer satisfaction and any of the four roles identified by Floyd and Wooldridge (see Table 5). This finding fails to support the idea that the primary focus of CI practices such as Lean is to eliminate activities that do not add customer value and address value-adding activities (Cudney \& Elrod 2011). If middle managers adopt a more synthesizing role here, the organization would be better able to monitor and evaluate the impact of changes in the environment, including activities of competitors and suppliers (Floyd \& Wooldridge 1992). In line with this, the implementing role of middle managers regarding CI may help safeguard customer focus among employees (Floyd \& Wooldridge 1992; Gulati \& Oldroyd 2005). One possible explanation of this result of the experiment is that the description of the customer and customer needs was not clear enough in the GOLD case text and survey. 


\subsection{Limitations}

This study has a number of limitations. First, although the results are insightful, our study was performed within a single organization, which makes the results potentially less generalizable. Replications of this study in other financial service organizations are thus recommended.

Second, the findings may not be generalizable outside the Netherlands. We have no direct evidence for this limitation, because the national cultural dimension has not been explicitly addressed in this study. Thus, future work should explore the potential impact of national culture.

Third, more conclusive results could have been generated if the sample size had been bigger. For future work in this area, obtaining a larger sample size would therefore be important.

Fourth, the simulated nature of the experiment may, when it comes to the emotional side of human perception (e.g. middle management roles), not provide the same setting as a real-life organizational context. As a result, our experiment is limited in its external validity (Roe \& Just 2009; Schram 2005). On the other hand, the substantial number of years of management experience of the participants in our sample implies that the vignettes provide a context they are familiar with based on their professional experience. In turn, this positively affects external validity (e.g. Barends et al. 2014; Buchanan 2008; Rouleau \& Balogun 2011). Hence, we hope that future work will replicate and extend our findings in field studies of real-life CI initiatives.

Fifth, the effect size of the various statements is quite small. This does not mean that the outcomes are not valuable, but they need to be interpreted with caution and thereby invite further investigation.

Finally, this study did not consider in an objective manner the extent to which CI was accomplished in a specific organization, and what the impact of the different roles was on this accomplishment. Rather, the study focused on perceptions, intentions and expectations that the participants had with respect to the impact of the roles investigated. One could, therefore, state that the internal validity of the findings arising from this study are limited (cf. Roe \& Just 2009; Schram 2005). As such, it would be valuable to examine real-life cases in which CI is implemented and determine the impact the various roles have in these cases. The proposed causal relationships arising from our study can inform such investigations.

\subsection{Conclusion and Further Research}

In sum, middle management can be expected to have a role in accomplishing CI throughout the organization, by acting as "a cornerstone between top management and bottom line workers" (Al-Najem 2012, p. 119). In addition, if middle managers feel they are not sufficiently involved at an early stage of the CI effort, they are not likely to become the change agents they possibly can be (Holmemo \& Ingvaldsen 2016; Lleo et al. 2017). In successful interventions middle managers have been included and activated at an early stage of the process (Davis \& Fisher 2002) and top management creates a culture that makes it easier for middle managers to be involved in quality improvement and embed it in the organization (Balding 2005). Our findings indicate that the implementing and synthesizing roles of middle management appear to be of importance in the context of CI initiatives, while the facilitating and championing roles appear to be less relevant.

The main findings from this study demonstrate that middle managers can be seen as change agents, in line with existing work (Balogun 2003; Buick et al. 2018; Kuyvenhoven \& Buss 2011; Westley 1990), involving both upward and downward activities (Wooldridge et al. 2008). Following research by Reid (1989), our findings show that most middle managers in our sample think of themselves as implementers and that they engage in this role much more than the other three roles (Floyd \& Wooldridge 1992).

Changes within organizations have become the norm rather than the exception (Schaffer 2017). This requires even more adaptive organizations that are willing and able to change. To accomplish this, organizations are increasingly using the concept of agility, in addition to Lean and other CI methods (Harraf et al. 2015; Rigby et al. 2016), which changes the role of middle managers (De Smet 2018). It is expected that middle management will continue to pay an important role within them. The importance of effective management has apparently not changed, but the way one engages in management may be changing fundamentally. In response to altering customer behavior, shorter times-to-market, shifting expectations of employees, and increasing digitalization, organizations are changing rapidly and need to become more agile. Middle management is an important link in these transformation processes. This in itself requires personal adaptability and a new interpretation of the role of middle management. Thus, the impact that an agile way of working has on the role of middle management is an interesting area for future research, in particular to find out which roles (i.e. championing, synthesizing or implementing) can contribute the most to accomplishing organizational agility. 


\section{References}

Ahearne, M., Lam, S. K., \& Kraus, F. (2014). Performance impact of middle managers' adaptive strategy implementation: The role of social capital. Strategic Management Journal, 35(1), 68-87. https://doi.org/10.1002/smj.2086

Al-Najem, M., Dhakal, H., \& Bennett, N. (2012). The role of culture and leadership in lean transformation: A review and assessment model. International Journal of Lean Thinking, 3(1), 119-138.

Aloini, D., Martini, A., \& Pellegrini, L. (2011). A structural equation model for continuous improvement: A test for capabilities, tools and performance. Production Planning \& Control, 22(7), 628-648. https://doi.org/10.1080/09537287.2010.508759

Angelis, J., Conti, R., Cooper, C., \& Gill, C. (2011). Building a high-commitment lean culture. Journal of Manufacturing Technology Management, 22(5), 569-586. https://doi.org/10.1108/17410381111134446

Anicich, E. M., \& Hirsh, J. B. (2017, March). Why being a middle manager is so exhausting. HBR.org digital article. Retrieved from https://hbr.org/2017/03/why-being-a-middle-manager-is-so-exhausting

Argyris, C. (2004). Reasons and Rationalizations: The Limits to Organizational Knowledge. Oxford: Oxford University Press. https://doi.org/10.1093/acprof:oso/9780199268078.001.0001

Atkinson, P. (2010). Lean is a cultural issue. Management Services, 54(2), 35-41.

Balding, C. (2005). Embedding organisational quality improvement through middle manager ownership. International Journal of Health Care Quality Assurance, 18(4), 271-288. https://doi.org/10.1108/09526860510602541

Balogun, J. (2003). From blaming the middle to harnessing its potential: Creating change intermediaries. British Journal of Management, 14(1), 69-83. https://doi.org/10.1111/1467-8551.00266

Balogun, J., \& Johnson, G. (2004). Organizational restructuring and middle manager sensemaking. Academy of Management Journal, 47(4), 523-549. https://doi.org/10.2307/20159600

Barends, E., Janssen, B., ten Have, W., \& ten Have, S. (2014). Difficult but doable: Increasing the internal validity of organizational change management studies. The Journal of Applied Behavioral Science, 50(1), 50-54. https://doi.org/10.1177/0021886313515614

Basu, P., \& Ahmed, P. (2012). The employee perspective in Lean environment. Drishtikon Management Journal, $3(3), 1-25$.

Bateman, N. (2005). Sustainability: The elusive element of process improvement. International Journal of Operations \& Production Management, 25(3), 261-276. https://doi.org/10.1108/01443570510581862

Bateman, N., \& David, A. (2002). Process improvement programmes: A model for assessing sustainability. Journal of Operations \& Production Management, 22, 515-526. https://doi.org/10.1108/01443570210425156

Bessant, J., \& Francis, D. (1999). Developing strategic continuous improvement capability. International Journal of Operations \& Production Management, 19(11), 1106-1119. https://doi.org/10.1108/01443579910291032

Bessant, J., Caffyn, S., \& Gallagher, M. (2001). An evolutionary model of continuous improvement behavior. Technovation, 21(2), 67-77. https://doi.org/10.1016/S0166-4972(00)00023-7

Bhasin, S. (2011). Performance of organisations treating lean as an ideology. Business Process Management Journal, 17(6), 986-1011. https://doi.org/10.1108/14637151111182729

Bhasin, S. (2012a). An appropriate change strategy for lean success. Management Decision, 50, 439-458. https://doi.org/10.1108/00251741211216223

Bhasin, S. (2012b). Prominent obstacles to lean. International Journal of Productivity and Performance Management, 61(4), 403-425. https://doi.org/10.1108/17410401211212661

Bhuiyan, N., Baghel, A., \& Wilson, J. (2006). A sustainable continuous improvement methodology at an aerospace company. International Journal of Productivity and Performance Management, 55, 671-687. https://doi.org/10.1108/17410400610710206

Bicheno, J. (2008). The lean toolbox for service systems. Picsie books, Buckingham.

Birkinshaw, J., Hamel, G., \& Mol, M. (2008). Management innovation. Academy of Management Review, 33(4), 
825-845. https://doi.org/10.5465/amr.2008.34421969

Blom, T. (2018). Organisational wellness: Human reaction to change. South African Journal of Business Management, 49(1), 1-10. https://doi.org/10.4102/sajbm.v49i1.2

Boyle, T., Scherrer-Rathje, M., \& Stuart, I. (2011). Learning to be Lean: The influence of external information sources in lean improvements. Journal of Manufacturing Technology Management, 22(5), 587-603. https://doi.org/10.1108/17410381111134455

Buchanan, D. A. (2008). You stab my back, I'll stab yours: Management experience and perceptions of organization political behaviour. British Journal of Management, 19(1), 49-64. https://doi.org/10.1111/j.1467-8551.2007.00533.x

Buick, F., Blackman, D., \& Johnson, S. (2018). Enabling middle managers as change agents: Why organisational support needs to change. Australian Journal of Public Administration, 77(2), 222-235. https://doi.org/10.1111/1467-8500.12293

Cândido, C. J., \& Santos, S. P. (2019). Implementation obstacles and strategy implementation failure. Baltic Journal of Management, 14, 39-57. https://doi.org/10.1108/BJM-11-2017-0350

Carlborg, P., Kindström, D., \& Kowalkowski, C. (2013). A Lean approach to service productivity improvements: Synergy or oxymoron? Managing Service Quality, 23(4), 291-304. https://doi.org/10.1108/MSQ-04-2013-0052

Chandler, A. D. (1977). The visible hand: The managerial revolution in American business. Harvard University Press: Cambridge.

Clarke, M. (1998). Can specialists be general managers? Developing paradoxical thinking in middle managers. Journal of Management Development, 17, 191-206. https://doi.org/10.1108/02621719810210730

Collis, D. (2016). Lean strategy. Harvard Business Review, 94(2), 62-68.

Cudney, E., \& Elrod, C. (2011). A comparative analysis of integrating Lean concepts into supply chain management in manufacturing and service industries. International Journal of Lean Six Sigma, 2, 5-22. https://doi.org/10.1108/20401461111119422

Currie, G., \& Procter, S. (2005). The antecedents of middle managers' strategic contribution: The case of a professional bureaucracy. Journal of Management Studies, 42(7), 1325-1356. https://doi.org/10.1111/j.1467-6486.2005.00546.x

Dahlgaard, J., \& Dahlgaard-Park, S. (2006). Lean production, six sigma quality, TQM and company culture. The TQM Magazine, 18(3), 263-281. https://doi.org/10.1108/09544780610659998

Dale, B. (1996). Sustaining a process of continuous improvement: Definition and key factors. The TQM Magazine, 8(2), 49-51. https://doi.org/10.1108/09544789610114867

Davis, D., \& Fisher, T. (2002). Attitudes of middle managers to quality-based organisational change. Managing Service Quality, 12(6), 405-413. https://doi.org/10.1108/09604520210451885

De Smet, A. (2018). The agile manager, The McKinsey Quarterly, 3, 76-81.

De Waal, A. (2018). Success factors of high performance organization transformations. Measuring Business Excellence, 22, 375-390. https://doi.org/10.1108/MBE-08-2018-0055

Delbridge, R., \& Barton, H. (2002). Organizing for continuous improvement: Structures and roles in automotive components plants. International Journal of Operations \& Production Management, 22, 680-692. https://doi.org/10.1108/01443570210427686

Delizonna, L. (2017, August). High-performing teams need psychological safety. Here's how to create it. Harvard Business Review Digital Articles, Retrieved from https://hbr.org/2017/08/high-performing-teams-need-psychological-safety-heres-how-to-create-it

Dopson, S., \& Stewart, R. (1990). What is happening to middle management? British Journal of Management, l(1), 3-16. https://doi.org/10.1111/j.1467-8551.1990.tb00151.x

Dopson, S., \& Stewart, R. (1993). Information technology, organizational restructuring and the future of middle management. New Technology, Work and Employment, 8(1), 10-20. https://doi.org/10.1111/j.1468-005X.1993.tb00030.x

Drew, J., McCallum, B., \& Roggenhofer, S. (2004). Journey to Lean. Palgrave, New York. 
https://doi.org/10.1057/9781403948410

Embertson, M. K. (2006). The importance of middle managers in healthcare organizations. Journal of Healthcare Management, 51(4), 223-232. https://doi.org/10.1097/00115514-200607000-00005

Engle, R. L., Lopez, E. R., Gormley, K. E., Chan, J. A., Charns, M. P., \& Lukas, C. V. (2017). What roles do middle managers play in implementation of innovative practices? Health care management review, 42(1), 14-27. https://doi.org/10.1097/HMR.0000000000000090

Fine, D., Hansen, M., \& Roggenhofer, S. (2008). From lean to lasting: Making operational improvements stick. The McKinsey Quarterly, 108-118.

Floyd, S. W., \& Lane, P. J. (2000). Strategizing throughout the organization: Managing role conflict in strategic renewal. Academy of Management Review, 25(1), 154-177. https://doi.org/10.5465/amr.2000.2791608

Floyd, S. W., \& Wooldridge, B. (1992). Middle management involvement in strategy and its association with strategic type: A research note. Strategic Management Journal, 13, Special Issue "Strategy Process: Managing Corporate Self-Renewal”, 153-167. https://doi.org/10.1002/smj.4250131012

Floyd, S., \& Wooldridge, B. (1994). Dinosaurs or dynamos? Recognizing middle management's strategic role. The Academy of Management Executive, 8(4), 47-57. https://doi.org/10.5465/ame.1994.9412071702

Floyd, S., \& Wooldridge, B. (1996). The strategic middle manager: How to create and sustain competitive advantage. Jossey- Bass, San Francisco.

Floyd, S., \& Wooldridge, B. (1997). Middle management's strategic influence and organizational performance. Journal of Management Studies. 34(3), 465-485. https://doi.org/10.1111/1467-6486.00059

Found, P. A., Van Dun, D. H., \& Fei, F. (2009). Leadership skills at different levels within a lean organization. Paper presented at the $20^{\text {th }}$ Annual Conference of the Production and Operations Management Society, Orlando, Florida.

Gatenby, M., Rees, C., Truss, C., Alfes, K., \& Soane, E. (2015). Managing change, or changing managers? The role of middle managers in UK public service reform. Public Management Review, 17(8), 1124-1145. https://doi.org/10.1080/14719037.2014.895028

Gulati, R., \& Oldroyd, J. B. (2005). The quest for customer focus. Harvard Business Review, 83(4), 92-101.

Guo, Y., Huy, Q. N., \& Xiao, Z. (2017). How middle managers manage the political environment to achieve market goals: Insights from China's state-owned enterprises. Strategic Management Journal, 38(3), 676-696. https://doi.org/10.1002/smj.2515

Guth, W. D., \& MacMillan, I. C. (1986). Strategy implementation versus middle management self-interest, Strategic Management Journal (1986-1998), 7(4), 313-327. https://doi.org/10.1002/smj.4250070403

Hammer, M., \& Champy, J. (1993). Reengineerinjg the corporation: A manifesto for business revolution, HarperBusiness, New York. https://doi.org/10.1016/S0007-6813(05)80064-3

Harding, N., Lee, H., \& Ford, J. (2014). Who is 'the middle manager'? Human relations, 67(10), 1213-1237. https://doi.org/10.1177/0018726713516654

Harraf, A., Wanasika, I., Tate, K., \& Talbott, K. (2015). Organizational agility. Journal of Applied Business Research, 31(2), 675-686. https://doi.org/10.19030/jabr.v31i2.9160

Hermkens, F. J. A., Dolmans, S. A. M., \& Romme, A. G. L. (2017). The role of middle managers in becoming Lean: A systematic review and synthesis of the literature. Journal of Economics, Management \& Trade, 20, 1-17. https://doi.org/10.9734/JEMT/2017/38100

Hernández, J., \& Mateo, R. (2012). Indications of virtues in conscientiousness and its practice through continuous improvement. Business Ethics: A European Review, 21(2), 140-153. https://doi.org/10.1111/j.1467-8608.2011.01650.x

Heyden, M. L., Fourné, S. P., Koene, B. A., Werkman, R., \& Ansari, S. (2017). Rethinking 'top-down'and 'bottom-up'roles of top and middle managers in organizational change: Implications for employee support. Journal of Management Studies, 54(7), 961-985. https://doi.org/10.1111/joms.12258

Hines, P., Found, P., Griffiths, G., \& Harrison, R. (2011). Staying Lean: Thriving, not just surviving (2nd ed.). Productivity Press, New York.

Hines, P., Taylor, D., \& Walsh, A. (2018). The Lean journey: Have we got it wrong? Total Quality Management 
\& Business Excellence, 1-18.

Holmemo, M. D. Q., \& Ingvaldsen, J. A. (2016). Bypassing the dinosaurs? How middle managers become the missing link in lean implementation. Total Quality Management \& Business Excellence, 27(11-12), 1332-1345. https://doi.org/10.1080/14783363.2015.1075876

Holweg, M. (2007). The genealogy of Lean production. Journal of Operations Management, 25(2), $420-437$. https://doi.org/10.1016/j.jom.2006.04.001

Huy, Q. (2001). In praise of middle managers. Harvard Business Review, 79(8), 72-79.

Huy, Q. (2002). Emotional balancing of organizational continuity and radical change: The contribution of middle managers. Administrative Science Quarterly, 47(1), 31-69. https://doi.org/10.2307/3094890

Huy, Q. (2011). How middle managers' group-focus emotions and social identities influence strategy implementation. Strategic Management Journal, 32(13), 1387-1410. https://doi.org/10.1002/smj.961

Jaoua, F. (2016). Place of middle managers on the relationship between creativity in strategy and organisational performance. International Journal of Management and Decision Making, 15(2), 113-133. https://doi.org/10.1504/IJMDM.2016.077762

Jayaram, J., Vickery, S., \& Droge, C. (2008). Relationship building, Lean strategy and firm performance: An exploratory study in the automotive supplier industry. International Journal of Production Research, 46(20), 5633-5649. https://doi.org/10.1080/00207540701429942

Jørgensen, F., Boer, H., \& Gertsen, F. (2003). Jump-starting continuous improvement through self-assessment. International Journal of Operations \& Production Management, 23(10), 1260-1278. https://doi.org/10.1108/01443570310496661

Kim, Y. H., Sting, F. J., \& Loch, C. H. (2014). Top-down, bottom-up, or both? Toward an integrative perspective on operations strategy formation. Journal of Operations Management, 32(7-8), 462-474. https://doi.org/10.1016/j.jom.2014.09.005

Kras, K. R., Rudes, D. S., \& Taxman, F. S. (2017). Managing up and down: Community corrections middle managers' role conflict and ambiguity during organizational change. Journal of crime and justice, 40(2), 173-187. https://doi.org/10.1080/0735648X.2015.1085889

Kuyvenhoven, R., \& Buss, W. C. (2011). A normative view of the role of middle management in the implementation of strategic change. Journal of Management and Marketing Research, 8, 1-14.

Lam, M., O'Donnell, M., \& Robertson, D. (2015). Achieving employee commitment for continuous improvement initiatives. International Journal of Operations \& Production Management, 35(2), 201-205. https://doi.org/10.1108/IJOPM-03-2013-0134

Likert, R. (1961). New patterns of management. New York, McGraw-Hill.

Lleo, A., Viles, E., Jurburg, D., \& Lomas, L. (2017). Strengthening employee participation and commitment to continuous improvement through middle manager trustworthy behaviours. Total Quality Management \& Business Excellence, 28(9-10), 974-988. https://doi.org/10.1080/14783363.2017.1303872

Madhani, P. M. (2017). Customer-focused supply chain strategy: Developing business value-added framework. IUP Journal of Supply Chain Management, 14(4), 7-22.

Mair, J. (2017). Middle managers and corporate entrepreneurship: Unpacking strategic roles and assessing performance implications. In Handbook of Middle Management Strategy Process Research. Edward Elgar Publishing. https://doi.org/10.4337/9781783473250.00029

Mann, D. (2009). The missing link: Lean leadership. Frontiers of Health Services Management, 26(1), 15-26. https://doi.org/10.1097/01974520-200907000-00003

McLean, R. S., Antony, J., \& Dahlgaard, J. J. (2017). Failure of continuous improvement initiatives in manufacturing environments: A systematic review of the evidence. Total Quality Management \& Business Excellence, 28(3-4), 219-237. https://doi.org/10.1080/14783363.2015.1063414

McQuade, D. (2008). New development: Leading Lean action to transform housing services. Public Money and Management, 28(1), 57-60.

Miles, M. B., Huberman, A. M., \& Saldaña, J. (2014). Qualitative data analysis: A methods sourcebook (3rd ed.). Sage, Calafornia. 
Moss, K. R. (1982). The middle manager as innovator. Harvard Business Review, 60(4), 95-106.

Nelson, S., \& Yeo, R. (2012). Action learning for middle management development: The case of an Australian state-based large organization. International Journal Human Resources Development and Management, 12(4), 292-307. https://doi.org/10.1504/IJHRDM.2012.049784

Netland, T. H. (2016). Critical success factors for implementing Lean production: The effect of contingencies. International Journal of Production Research, 54(8), 2433-2448. https://doi.org/10.1080/00207543.2015.1096976

Neto, R. R., \& Lavarda, R. A. B. (2017). The language studies in strategy as practice and the middle manager roles: An essay. REBRAE, 10, 366-380. https://doi.org/10.7213/rebrae.10.003.AO02

Nguyen, D. M. (2018). Critical success factors of Lean implementation in Vietnam manufacturing enterprices. Journal of Production Engineering, 21, 1-5. https://doi.org/10.24867/JPE-2018-01-001

Nonaka, I. (1994). A dynamic theory of knowledge creation. Organization Science, 5(1), 14-37. https://doi.org/10.1287/orsc.5.1.14

Nyhuis, P., Schulze, C. P., \& Klemke, T. (2010). Lean-Enablers-An approach to design Lean factories. The Business Review, 16(1), 113-119.

Oakland, J. (2011). Leadership and policy deployment: The backbone of TQM. Total Quality Management \& Business Excellence, 22(5), 517-534. https://doi.org/10.1080/14783363.2011.579407

O'Rourke, P. (2005). A multiple-case comparison of Lean six sigma deployment and implementation strategies. ASQ World Conference on Quality and Improvement proceedings, 59, 581-591.

Osterman, P. (2008). The truth about middle managers. Harvard Business Press, Boston.

Ouakouak, M. L., Ouedraogo, N., \& Mbengue, A. (2014). The mediating role of organizational capabilities in the relationship between middle managers' involvement and firm performance: A European study. European Management Journal, 32(2), 305-318. https://doi.org/10.1016/j.emj.2013.03.002

Poksinska, B., Swartling, D., \& Drotz, E. (2013). The daily work of Lean leaders-lessons from manufacturing and healthcare. Total Quality Management \& Business Excellence, 24(7-8), 886-898. https://doi.org/10.1080/14783363.2013.791098

Raes, A. M. L., Heijltjes, M. G., Glunk, U., \& Roe, R. A. (2011). The interface of top management team and middle managers: A process model. Academy of Management Review, 36(1), 1-6. https://doi.org/10.5465/amr.2009.0088

Rahman, S., Laosirihongthong, T., \& Sohal, A. S. (2010). Impact of lean strategy on operational performance: A study of Thai manufacturing companies. Journal of Manufacturing Technology Management, 21(7), 839-852. https://doi.org/10.1108/17410381011077946

Reid, D. M. (1989). Operationalizing strategic planning. Strategic Management Journal, 10(6), 553-567. https://doi.org/10.1002/smj.4250100604

Rigby, D. K., Sutherland, J., \& Takeuchi, H. (2016). Embracing Agile. Harvard Business Review, 94(5), 40-50.

Roe, B. E., \& Just, D. R. (2009). Internal and external validity in economics research: Tradeoffs between experiments, field experiments, natural experiments, and field data. American Journal of Agricultural Economics, 91(5), 1266-1271. https://doi.org/10.1111/j.1467-8276.2009.01295.x

Rother, M. (2010). Toyota kata. MacGraw Hill, New York.

Rouleau, L., \& Balogun, J. (2011). Middle managers, strategic sensemaking, and discursive competence. Journal of Management Studies, 48(5), 953-983. https://doi.org/10.1111/j.1467-6486.2010.00941.x

Saha, N., Gregar, A., \& Sáha, P. (2017). Organizational agility and HRM strategy: Do they really enhance firms' competitiveness? International Journal of Organizational Leadership, 6, 323-334. https://doi.org/10.33844/ijol.2017.60454

Salih, A., \& Doll, Y. (2013). A middle management perspective on strategy implementation, International Journal of Business and Management, 8, 32-39. https://doi.org/10.5539/ijbm.v8n22p32

Saunders, M., Lewis, P., \& Thornhill, A. (2009). Research methods for business students. Prentice Hall: London.

Saurin, T. A., Marodin, G. A., \& Ribeiro, J. L. D. (2011). A framework for assessing the use of lean production practices in manufacturing cells. International Journal of Production Research, 49(11), 3211-3230. 
https://doi.org/10.1080/00207543.2010.482567

Schaffer, R. H. (2017, October). All management is change management. Harvard Business Review Digital Articles. Retrieved from https://hbr.org/2017/10/all-management-is-change-management

Schram, A. (2005). Artificiality: The tension between internal and external validity in economic experiments. Journal of Economic Methodology, 12(2), 225-237. https://doi.org/10.1080/13501780500086081

Shi, W., Markoczy L. G., \& Dess, G. (2009). The role of middle management in the strategy process: Group affiliation, structural holes, and tertius iungens. Journal of Management, 35(6), 1453-1480. https://doi.org/10.1177/0149206309346338

Sims, D. (2003). Between the millstones: A narrative account of the vulnerability of middle managers' storying. Human Relations, 56(10), 1195-1211. https://doi.org/10.1177/00187267035610002

Snee, R. (2010). Lean Six Sigma - getting better all the time. International Journal of Lean Six Sigma, 1(1), 9-29. https://doi.org/10.1108/20401461011033130

Sreedharan, V. R., \& Sunder, M. V. (2018). Critical success factors of TQM, Six Sigma, Lean and Lean Six Sigma: A literature review and key findings. Benchmarking: An International Journal, 25(9), 3479-3504. https://doi.org/10.1108/BIJ-08-2017-0223

Stoker, J., \& De Korte, T. (2001). Het onmisbare middenkader (2nd ed.). Van Gorcum, Assen.

Tabrizi, B. (2014, October). The key to change is middle management. Harvard Business Review Digital Articles Retrieved from https://hbr.org/2014/10/the-key-to-change-is-middle-management

Tarakci, M., Ateş, N. Y., Floyd, S. W., Ahn, Y., \& Wooldridge, B. (2018). Performance feedback and middle managers' divergent strategic behavior: The roles of social comparisons and organizational identification. Strategic Management Journal, 39(4), 1139-1162. https://doi.org/10.1002/smj.2745

Van Assen, M. F. (2016). Exploring the impact of higher management's leadership styles on Lean management. Total Quality Management \& Business Excellence, 1-30.

Van Assen, M. F. (2018). The moderating effect of management behavior for Lean and process improvement. Operations Management Research, 11(1-2), 1-13. https://doi.org/10.1007/s12063-018-0129-8

Van Baarle, S., Dolmans, S. A. M., Bobelyn, A. S. A., \& Romme, A. G. L. (2019). Beyond command and control: Tensions arising from empowerment initiatives. Organization Studies. https://doi.org/10.1177/0170840618818600

Van der Voet, J., Kuipers, B. S., \& Groeneveld, S. (2016). Implementing change in public organizations: The relationship between leadership and affective commitment to change in a public sector context. Public Management Review, 18(6), 842-865. https://doi.org/10.1080/14719037.2015.1045020

Van Dun, D. H., \& Wilderom, C. P. M. (2016). Lean teams, In Netland, T. H., \& Powell, D. J. (Eds), The Routledge Companion to Lean Management. Routledge, New York, NY, 106-117.

Van Rensburg, M. J., Davis, A., \& Venter, P. (2014). Making strategy work: The role of the middle manager. Journal of Management \& Organization, 20(2), 165-186. https://doi.org/10.1017/jmo.2014.33

Vänje, A., \& Brännmark, M. (2017). Walking around the pyramids: Managers' shop-floor activities in Lean-inspired organizations. Economic and Industrial Democracy, 38(3), 495-512. https://doi.org/10.1177/0143831X15580351

Westley, F. (1990). Middle managers and strategy: Micro dynamics of inclusion. Strategic Management Journal, ll(5), 337-51. https://doi.org/10.1002/smj.4250110502

Wolf, C., \& Floyd, S. W. (2017). Strategic planning research: Toward a theory-driven agenda. Journal of Management, 43(6), 1754-1788. https://doi.org/10.1177/0149206313478185

Wooldridge, B., \& Floyd, S. W. (1990). The strategy process, middle management involvement, and organizational performance. Strategic Management Journal, 11(3), 231-241. https://doi.org/10.1002/smj.4250110305

Wooldridge, B., Schmidt, T., \& Floyd, S. W. (2008). The middle management perspective on strategy process: Contributions, synthesis, and future research. Journal of Management, 34(6), 1190-1221. https://doi.org/10.1177/0149206308324326 


\section{Appendix 1. Floyd and Wooldridge Self-Test of Middle Management Strategic Involvement}

1) Monitor and assess the impact of changes in the organization's external environment.
$\square$ Never
$\square$ Rarely
$\square$ Occasionally
$\square$ Regularly
$\square$ Frequently

2) Implement action plans designed to meet top management objectives.
$\square$ Never
$\square$ Rarely
$\square$ Occasionally
$\square$ Regularly
$\square$ Frequently

3) Integrate information from a variety of sources to communicate its strategic significance.
$\square$ Never
$\square$ Rarely
$\square$ Occasionally
$\square$ Regularly
$\square$ Frequently

4) Evaluate the merits of new proposals.
$\square$ Never
$\square$ Rarely
$\square$ Occasionally
$\square$ Regularly
$\square$ Frequently

5) Evaluate the merits of proposals generated in my unit, encouraging some, discouraging others.
$\square$ Never
$\square$ Rarely
$\square$ Occasionally
$\square$ Regularly
$\square$ Frequently

6) Translate organizational goals into objectives for individuals
$\square$ Never
$\square$ Rarely
$\square$ Occasionally
$\square$ Regularly
$\square$ Frequently

7) Provide a safe haven for experimental programs.
$\square$ Never
$\square$ Rarely
$\square$ Occasionally
$\square$ Regularly
$\square$ Frequently

8) Assess and communicate the business-level implications of new information to higher-level managers.
$\square$ Never
$\square$ Rarely
$\square$ Occasionally
$\square$ Regularly
$\square$ Frequently

9) Search for new opportunities and bring them to the attention of higher-level managers.
$\square$ Never
$\square$ Rarely
$\square$ Occasionally
$\square$ Regularly
$\square$ Frequently

10) Communicate and sell top management initiatives to subordinates.
$\square$ Never
$\square$ Rarely
$\square$ Occasionally
$\square$ Regularly
$\square$ Frequently

11) Define and justify the role of new programs or processes to upper-level managers.
$\square$ Never
$\square$ Rarely
$\square$ Occasionally
$\square$ Regularly
$\square$ Frequently

12) Encourage multidisciplinary problem-solving teams.
$\square$ Never
$\square$ Rarely
$\square$ Occasionally
$\square$ Regularly
$\square$ Frequently

13) Proactively seek information about your business from customers, suppliers, competitors, business publications, and so on.
$\square$ Never
$\square$ Rarely
$\square$ Occasionally
$\square$ Regularly
$\square$ Frequently

14) Monitor and communicate to higher-level managers the activities of competitors, suppliers, and other outside organizations 


$\square$ Never $\quad \square$ Rarely $\quad \square$ Occasionally $\quad \square$ Regularly $\quad \square$ Frequently

15) Justify to higher-level managers programs that have already been established.
$\square$ Never
$\square$ Rarely
$\square$ Occasionally
$\square$ Regularly
$\square$ Frequently

16) Provide resources and develop objectives/strategies for unofficial projects.
$\square$ Never
$\square$ Rarely
$\square$ Occasionally
$\square$ Regularly
$\square$ Frequently

17) Translate organizational goals into departmental action plans.
$\square$ Never
$\square$ Rarely
$\square$ Occasionally
$\square$ Regularly
$\square$ Frequently

18) Relax regulations and procedures in order to get new projects started.
$\square$ Never
$\square$ Rarely
$\square$ Occasionally
$\square$ Regularly
$\square$ Frequently

19) Propose new programs or projects to higher-level managers.
$\square$ Never
$\square$ Rarely
$\square$ Occasionally
$\square$ Regularly
$\square$ Frequently

20) Monitor activities within your unit to ensure that they support top management objectives.
$\square$ Never
$\square$ Rarely
$\square$ Occasionally
$\square$ Regularly
$\square$ Frequently

\section{Appendix 2. Experiment Questionnaire}

Please answer the questions below. Do this by answering each question with: totally disagree, disagree, not disagree/ not agree, agree or totally agree.

1) I consider GOLD as an implementation of the continuous improvement philosophy.
$\square$ totally disagree
$\square$ disagree
$\square$ not disagree/not
$\square$ agree
$\square$ totally agree

agree

2) I consider GOLD as a program that results in a permanent shift of our organizational culture.
$\square$ totally disagree
$\square$ disagree
$\square$ not disagree/not
$\square$ agree
$\square$ totally agree

agree

3) I consider GOLD as an effort to increase the efficiency of the organization.
$\square$ totally disagree
$\square$ disagree
$\square$ not disagree/not
$\square$ agree
$\square$ totally agree

agree

4) I consider GOLD as a threat to my function.
totally disagree
$\square$ disagree
$\square$ not disagree/not
$\square$ agree
$\square$ totally agree
agree

5) GOLD results in the implementation of continuous improvement within our culture.
$\square$ totally disagree
$\square$ disagree
$\square$ not disagree/not
$\square$ agree
$\square$ totally agree
agree 
6) GOLD results in a drastic cost decrease.

$\square$ totally disagree $\quad \square$ disagree $\quad \square$ not disagree/not $\quad \square$ agree $\quad \square$ totally agree

7) The working atmosphere will improve due to the implementation of GOLD.
$\square$ totally disagree
$\square$ disagree
$\square$ not disagree/not
$\square$ agree
$\square$ totally agree
agree

8) I will support the top management during the implementation of the change (GOLD).
totally disagree
$\square$ disagree
$\square$ not disagree/not
$\square$ agree
$\square$ totally agree
agree

9) I will fulfil a pioneering role in making GOLD a success.

$\square$ totally disagree $\quad \square$ disagree $\quad \square$ not disagree/not $\quad \square$ agree $\quad \square$ totally agree

10) I perceive my role as crucial within the GOLD program.
$\square$ totally disagree
$\square$ disagree
$\square$ not disagree/not
agree
$\square$ agree
$\square$ totally agree

11) Because of GOLD, I focus on fulfilling customer needs.

$\square$ totally disagree $\quad \square$ disagree $\quad \square$ not disagree/not $\begin{gathered}\text { agree } \\ \text { agree }\end{gathered}$ totally agree

12) I will investigate how GOLD can contribute to customer satisfaction.

$\square$ totally disagree $\quad \square$ disagree $\quad \square$ not disagree/not $\quad \square$ agree $\quad \square$ totally agree agree

13) I will integrate GOLD and adapt it to the current way of working within my department(s)

$\square$ totally disagree $\quad \square$ disagree $\quad \square$ not disagree/not $\quad \square$ agree $\quad \square$ totally agree agree

14) In the context of GOLD, I will adapt the organization in order to meet customer needs in the best possible way.

$\square$ totally disagree $\quad \square$ disagree $\quad \square$ not disagree/not $\quad \square$ agree $\quad \square$ totally agree

15) Because of GOLD, I focus on fulfilling customer needs at the lowest possible costs and shortest lead time.
$\square$ totally disagree
$\square$ disagree
$\square$ not disagree/not
agree
$\square$ agree
$\square$ totally agree

16) I select the proper tools to achieve and monitor the GOLD objectives. 
agree

17) I will determine specific KPI's to timely realize the efficiency objectives of GOLD.

$\square$ totally disagree $\quad \square$ disagree $\quad \square$ not disagree/not $\quad \square$ agree $\quad \square$ totally agree

$$
\text { agree }
$$

18) In the context of GOLD, I actively monitor individual and team KPI's in order to identify improvement possibilities.

$\square$ totally disagree $\quad \square$ disagree $\quad \square$ not disagree/not $\quad \square$ agree $\quad \square$ totally agree agree

19) By implementing GOLD, I will solely focus on activities that are beneficial for me.

$\square$ totally disagree $\quad \square$ disagree $\quad \square$ not disagree/not $\quad \square$ agree $\quad \square$ totally agree agree

20) Because of GOLD, I will steer the department on efficiency.

\begin{tabular}{|c|c|c|c|c|}
\hline totally disagree & $\square$ disagree & $\square$ not disagree/not & $\square$ agree & $\square$ totally agree \\
\hline
\end{tabular}

21) Because of GOLD, I will steer the department on customer satisfaction.

totally disagree $\quad \square$ disagree $\quad \square$ not disagree/not $\quad \square$ agree $\quad \square$ totally agree

agree

22) Because of GOLD, I will steer the department on achieving continuous improvement and the adaption to a new organizational culture.

$\square$ totally disagree $\quad \square$ disagree $\quad \square$ not disagree/not $\quad \square$ agree $\quad \square$ totally agree agree

General questions

\begin{tabular}{|r|l|}
\hline Gender & \\
\hline Function & \\
\hline Education level & $\square$ Elementary school \\
& $\square$ High school \\
& $\square$ MBO \\
& $\square$ HBO \\
& $\square$ University \\
& $\square$ Post-doctoral education \\
\hline Amount of years working & $\square$-3 years \\
at ABN AMRO & $\square$ 3-5 years \\
& $\square$ 6-10 years \\
& $\square$ more than 10 years \\
\hline Amount of years at & $\square 0$-3 years \\
current department & $\square$ 3-5 years \\
& $\square$ 6-10 years \\
& $\square$ more than 10 years \\
\hline Years of experience with & \\
CE/CI &
\end{tabular}




\section{Open question}

Do you believe that your organization will still work according to Customer Excellence within 5 years? Why yes/no?

\section{Copyrights}

Copyright for this article is retained by the author(s), with first publication rights granted to the journal.

This is an open-access article distributed under the terms and conditions of the Creative Commons Attribution license (http://creativecommons.org/licenses/by/4.0/). 